\title{
Ocular manifestations of sickle cell disease in heterozygous subjects: Senegalese experience
}

Ka $\mathrm{AM}^{1 *}$, Ba EA ${ }^{2}$, Wane $\mathrm{AM}^{2}$, Sow $\mathrm{AS}^{2}$, Diagne $\mathrm{JP}^{1}$, De Medeiros $\mathrm{ME}^{1}$, Kane $\mathrm{H}^{2}$, Dieng $\mathrm{M}^{2}$, Mouen Bengue $\mathrm{G}^{2}$, Ndiaye JMM ${ }^{2}$, Sow $\mathrm{S}^{1}$, Nguer $\mathbf{M}^{2}$, Ndoye Roth $\mathrm{PA}^{2}$, Ndiaye $\mathrm{PA}^{1}$

${ }^{1}$ Department of Ophthalmology of Abass Ndao Hospital, Dakar (Senegal)

${ }^{2}$ Department of Ophthalmology of Aristide Le Dantec Hospital, Dakar (Senegal)

Received: September 28, 2018; Accepted:October 10, 2018; Published: October 13, 2018

*Corresponding author: Aly Mbara KA, Department of Ophthalmology of Abass Ndao Hospital, Dakar (Senegal), Phone: 00221775588815; Fax: 00221338420023; E-mail: kaam75@hotmail.com

\begin{abstract}
Introduction: Sickle cell disease is the most widespread hemoglobinopathy in the world and affects nearly $10 \%$ of the population in subSaharan Africa. It is responsible for ophthalmological manifestations very little described by the literature in our country. We report our experience
\end{abstract} of ocular lesions encountered in heterozygous sickle cell subjects monitored in our department.

Material and methods: From June 2004 to July 2011, we initiated a retrospective study which allowed us to recruit sickle cell patients for a research on ocular involvement. Each patient had complete ophthalmologic examination and fluorescein angiography. The descriptive analysis was carried out using the EPI-INFO software version 6.04 .

Results: Out of 80 patients received, eight were retained with a sex ratio of $0.6 \%$. The mean age was 34 years for extremes of 22 and 49 years. It was 50\% AS sickle-cell anemia and 50\% SC. On examination, the visual acuity (VA) varied from the absence of luminous perception to $10 / 10$. The lesions found were bilateral in 7 cases and unilateral for 1 case.

Comments: Sickle cell disease is a hemoglobinopathy which predominates in the black subject and the male gender is the most affected. The $\mathrm{SC}$ genotypic form is the main provider of sickle cell retinopathy. Moreover, the signs are more marked as the subject is older, whereas this intensity varies inversely according to the genotype; it is more important in the SC form then in AS and finally SS form.

Conclusion: The ocular lesions related to sickle cell disease are serious and involve the functional prognosis of the eye especially of young and black subjects.

Keywords: Sickle Cell Disease; Eye; Black Race

\section{Introduction}

Sickle cell disease is a genetic disease with autosomal recessive transmission due to the presence in the red blood cell of abnormal hemoglobin called hemoglobin S. It would be the most widespread hemoglobinopathy in the world affecting nearly 120 million people according to the WHO. This disease is very frequent in Africa south of Sahara, where in Senegal it affects almost $10 \%$ of the population. It is responsible for polymorphic clinical manifestations, in particular ophthalmologic. However, the latter are very little described by the literature in our country. We report our experience of ocular lesions found in heterozygous sickle cell subjects monitored in our department.

\section{Material and methods}

From June 2004 to July 2011, we initiated a retrospective study of sickle cell patients for screening for ocular disorders related to this disease. Each patient had a complete ophthalmologic examination (both socio-demographic and clinical) and fluorescein angiography. The sickle cell disease form was confirmed by the electrophoresis of hemoglobin. The descriptive analysis was carried out using the EPI-INFO software version 6.04 .

\section{Results}

From June 2004 to July 2011, 80 patients were examined, and among them 8 were selected. Our sample consisted of 3 men and 5 women. The mean age was 34 years for extremes of 22 and 49 years. The genotypic forms were SC in $50 \%$ of cases and AS in $50 \%$ of cases.

On examination, the VA varied between the absence of light perception at 10/10. At the level of the anterior and posterior segments lesions were bilateral in 7 cases (all AS and in 3 SC cases) and unilateral for 1 SC case. (Tables 1and 2). 


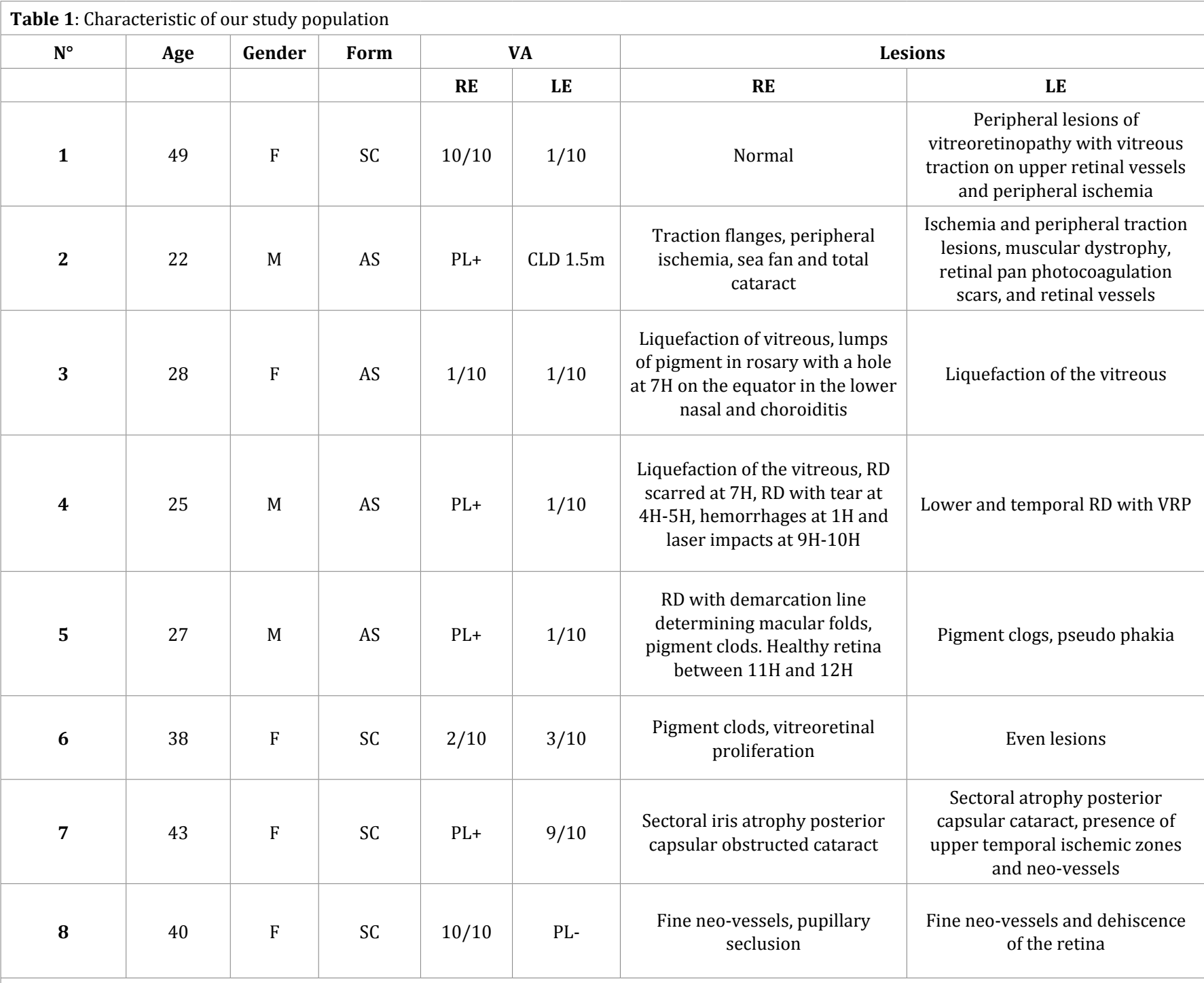

VA: Visual Acuity, CF: Counts the fingers, RD: Retinal detachment, PL+: Positive light perception, PL-: Negative light perception, Form: type of sickle cell disease, VRP: Vitreoretinal proliferation, RE: right eye, LE: left eye, M: male, F: female

Table 2: Frequency of damage to the posterior segment

\begin{tabular}{|c|c|c|c|c|c|c|c|}
\hline Lesion Form & Vitreous Liquefaction & Ischemia, Neo vessels & Pigment blocks & VRP & Holes, tears & RD & Gender \\
\hline AS & 2 Cases $(11.76 \%)$ & 1 Case $(5.88 \%)$ & 2 Cases $(11.76 \%)$ & $\begin{array}{c}1 \text { Case } \\
(5.88 \%)\end{array}$ & $\begin{array}{c}2 \text { Cases } \\
(11.76 \%)\end{array}$ & $\begin{array}{c}2 \text { Cases } \\
(11.76 \%)\end{array}$ & $3 \mathrm{M}, 1 \mathrm{~F}$ \\
\hline SC & 1 Case $(5.88 \%)$ & 3 Cases $(17.64 \%)$ & 1 Case $(5.88 \%)$ & $\begin{array}{c}2 \text { Cases } \\
(11.76 \%)\end{array}$ & 0 Case & 0 Case & $4 \mathrm{~F}$ \\
\hline
\end{tabular}

RD: Retinal detachment, VRP: Vitreoretinal proliferation, M: male, F: female

\section{Comments}

Sickle cell disease is a hemoglobinopathy which predominates in black subject [4,5]. According to various authors cited by Sanchez [5] such as Diallo and Wade, and also Pichard, Resnikoff and Gentillini, the overall prevalence varies from 5 to $20 \%$ in West Africa. Prevalence peaks of $40 \%$ have even been reported in Central Africa [5]. Moreover, the male gender would be more affected according to Fox PD [6], however in our sample there were $62.5 \%$ of women. The average age of our patients was 34 years. Indeed, the ocular manifestations of sickle cell disease are observed especially in the young adult. Thus Traore J. et al [7] find predominance between 26 and 35 years. Similarly, Fox PD et al [8] and Downes SM [9] find themselves respectively 20-39 years and 24-26 years.

Furthermore, the predominance of AS and SC forms in our serie is similar to the findings of Sanchez [5] who report that $8.4 \%$ of the Senegalese population is $\mathrm{AS}, 17 \% \mathrm{AC}$ and $1 \% \mathrm{SS}$. 
On the symptomatologic level, we did not find the classical conjunctival signs (pale and jaundice). This is probably related to the absence of the SS form in our serie. In fact, these signs are characteristic of sickle cell anemia in this form [5]. Our patients with SC phenotype received in consultation had VRP in half of the cases and a retinal ischemia in 3 quarters of the cases. According to Yehouessi [10], 65.4\% of cases of proliferative retinopathy are found in SC sickle-cell disease. In their series Balo and coll [11] found an overall prevalence of sickle cell retinopathy of $68 \%$. Based on these results, it should be noted that the SC genotypic form is therefore the provider of retinopathy, especially in its proliferative form.

Otherwise, two (2) AS patients had retinal detachment (RD). This complication, which constitutes the ultimate stage, has a relative frequency of 1 to $4 \%$ [12]. In general, SC patients are most affected by retinal detachment. Traore found $25.92 \%$ of retinal detachment in SC patients and John found it in 10\% of SC subjects [14]. Kabo [15] found a single case of retinal detachment in an AS patient. The presence of retinal detachment in our patients, especially carriers of the sickle cell trait, should be a wake-up call for practitioners. In fact, retinal damage in AS patients exists and are potentially serious.

However a study conducted in Canada in 2003 showed that healthy sickle cell trait carriers did not have an increased risk of retinopathy [16]. Morel also mentions the rarity of ocular involvement in AS patients [17].

Moreover, the signs would be more marked as the subject is older. Binaghi M and Levy C [18] and Fox PD and coll [6] also find this trend. On the contrary, this intensity varies inversely according to the genotype; It is more important in SC form then in AS and finally in SS $[6,18,19,20,21,22]$. The SC form would be the largest provider of ocular manifestations followed by the SS form and finally the AS form [18, 20, 22]. However, Fany A and coll [23] found that ocular lesions of sickle cell disease were frequent in the AS form but less pronounced than in the SC and SS forms. In our serie, the signs of vitreoretinal proliferation and peripheral retinal ischemia were observed at the same degree as in SC patients than in AS patients.

\section{Conclusion}

The ocular lesions associated with sickle cell anemia have been the subject of numerous publications. They are severe and involve the functional prognosis of the eye especially of young and black subjects. Their insidious evolution is always a cause of irreversible blindness, especially in our regions where delays in diagnosis are deplored. However, ocular signs in sickle cell anemia are not uncommon or less severe.

\section{References}

1. Weartherall DJ, Clegg JB. Inherited hemoglobin disorders:an increasing global health problem. Bull WHO. 2001;79(8):704-712.

2. Centro de referencia etiquetado como Enfermedades raras. "Síndromes de células falciformes mayores". Complicaciones oftalmológicas de la enfermedad de células falciformes en adultos. Recomendaciones de CRLMR, mayo de. 2009;1-2.
3. Mbodj M, Ndoye O, Diarra M, Mbaye B N, Sow Touré H. Dépistage néonatal de la drépanocytose au CHU de Dakar: premier bilan.Dakar. Med. 2003;48(3):202-205.

4. Diallo JS, Wade A, Ndiaye R. Manifestations oculaires de la drépanocytose. (In) : la maladie drépanocytaire de Begue P, Paris, Sandoz Ed. $1984 ; 173-179$.

5. Sanchez SA. These Med no 6, Dakar.1999.

6. Fox PD, Dunn DT, Morris JS, Serjeant GR. Risk factors for proliferative sickle retinopathy. Br J Ophthalmol. 1990;74 (3):172-176.

7. Traore J, Boitre JP, Bogoreh IA, Traore L, Diallo A. Sickle cell disease and retinal damage: a study of 38 cases at the African Tropical Ophthalmology Institute (IOTA) in Bamako. Med Trop (Mars). 2006;66(3):252-254.

8. Fox PD, Vessey SJ, Forshaw ML, Serjeant GR. Influence of genotype on natural history of untreated proliferative sickle retinopathy: an angiographic study. Br J Ophthalmol. 1991;75(4):229-231.

9. Downes SM, Hambleton IR, Chuang EL, Lois N, Serjeant GR, Bird AC. Incidence and natural history of proliferative sickle cell retinopathy: observations from a cohort study. Ophthalmology. 2005;112(11):18691875.

10. Yehouessi L, Anani L, Tchabi S, Doutetien C, Sounouvou I. Bilan des manifestations oculaires de la drépanocytose au CHNU - HKM de Cotonou. J Soc Biol Clin. 2007;11:22-26.

11. Balo KP, Segbena K, Mensah A, Milhuendo H, Bechetoille A. Hémoglobinopathies et rétinopathies au CHU de Lomé. J Fr Ophtalmol. 1996;19(8-9):497- 504.

12. Lawton AW. Sickle cell and the eye. Association of Black Nursing Faculty J.1996;7(3):78-80.

13. Traoré J, Boitte FP, Bogoreh A, Traoré L, Diallo A. Drépanocytose et atteintes rétiniennes : étude de 38 cas à l'institut d'ophtalmologie Tropicale d'Afrique. Med Trop. 2006;66(3):252-254.

14.Clarkson JG. The ocular manifestations of sickle cell disease: A prevalence and natural history study. Trans Am Opht Soc. 1992;90:481504.

15. Kabo AM, Mazou AH. Manifestations oculaires de la drépanocytose à l'hôpital national de Niamey (Niger). Med Afr Noire. 1988;35:447-450.

16. Nia J, Lam WC, Kleinman DM, Kriby M, Liu ES, Eng KT. Retinopathy in sickle disease cell trait: does it exist?. Can J Ophthalmol. 2003;38(1):4651.

17. Morel C. Atteintes rétiniennes des hémoglobinopathies. J Fr Ophtalmol. 2001;24(9);987-992.

18. Binaghi M, Lévy C. oeil et hémoglobinopathies. EMC. 1993:21-452-G20.

19. Babalola OE, Wambebe CO. When children and young adults with sickle cell disease should be referred for eye assessment. Afr J Med Med Sci. 2001;30(4):261-263.

20. Balo KP, Fany A, MihluedonH, Djagnikpo PA, Kooffi-Gue KB. Retinal involvement in drepanocytosis in Togo. Correlation between age, genotype and retinopathy. J Fr Ophtalmol. 1997;20(9):653-658.

21. Eruchalu UV, Pam VA, Akuse RM. Ocular findings in children with severe clinical symptoms of homozygous sickle cell anemia in Kaduna, Nigeria. West Afr J Med. 2006;25(2):88-91.

22. Penman AD, Talbot JF, Chuang EL, Thomas P, Serjeant GR, Bird AC. New classification of peripheral retinal vascular changes in sickle cell disease. Br J Ophthalmol. 1994;78(9):681-689.

23. Fany A, Boni S, Adjorlolo C, Konan ML, Gbe K, Coulalibaly F, Berete R, et al. Retinopathy as a sickle-cell trait: myth or reality? J Fr Ophtalmol. 2004;27:1025-1030. 